\title{
Comprehensive Analysis of the Coated Component from a FORD Engine
}

Iryna Hren (0000-0003-3942-2481), Štefan Michna (0000-0001-5893-5050), Jan Novotný (0000-0001-7676-8495), Lenka Michnová (0000-0003-0191-4632)

Faculty of Mechanical Engineering, J. E. Purkyne University in Usti nad Labem. Pasteurova 3334/7, 40001 Usti nad Labem.Czech Republic.E-mail: iryna.hren@ujep.cz, stefan.michna@ujep.cz, jan.novotny@ujep.cz, lenka.michnova@ujep.cz

The article is devoted to a comprehensive analysis of the coating of a component from the Ford Focus 1.0 1 EcoBoost engine. It is one of a pair of materially identical aluminum gears connected by a drive pulley and a drive. Aluminum gear components are surface treated with a mixture of metal powders using PVD technology, where the goal of the coating is to increase the hardness, abrasion resistance and heat of the base material. The chemical composition of the basic material of the geared aluminum drive wheel of the FORD engine proves that it is a component made by thermoforming and corresponds to the alloy EN AW 6061 (AlMg1SiCu) according to the standard ČSN EN 573 1-3. The microstructure of the base material component exhibits fine intermetallic phases evenly distributed throughout the cross-section of the base base material, without the occurrence of larger inclusions and/or porosity. The cross-sectional microstructure in the area of the coating demonstrates that the component has a continuous uniform surface layer of the coating formed without a defect and does not have a diffuse bond with the base material. The measurement of the coating thickness of the component shows a continuous surface layer formed by powder metallography, which ranges from $70.1 \mu \mathrm{m}$ to $143.9 \mu \mathrm{m}$. The surface EDS of the surface proves that it consists of deposited tungsten carbides produced by powder metallography and the bonding material is cobalt. Area EDS analysis of the surface coating identified morphologically two distinct areas of dark and light, where tungsten carbides and cobalt are based, and only the tungsten carbide and cobalt carbide contents change. The oxygen and carbon content also changes in the dark and light areas.

Keywords: FORD engine, component, coating, base material, scanning electron microscopy, EDS analysis, metallographic analysis, chemical analysis.

\section{Introduction}

Ford Motor Company is producing a new version of the low-emission Model 1.0L EcoBoost engine (Fig. 1), which is the first family petrol car in Europe with $\mathrm{CO}_{2}$ emissions of $99 \mathrm{~g} / \mathrm{km}$ [1]. The Focus $1.0 \mathrm{~L}$ EcoBoost has a fuel consumption of 4.3 liters/100 $\mathrm{km}$, which is equipped with a specially calibrated version of the 1.0L direct-injection petrol engine with a power output of $100 \mathrm{hp}$ (74 hp), will also include Ford ECOnetic Technology including Auto-StartStop, Smart Regenerative Charging, Active Grille Shutter and Ford EcoMode, which support a more economical and environmentally friendly driving style. The Ford EcoBoost engine has a transverse three-cylinder direct-injection turbocharger with Ti-VCT. It uses a low-inertia turbocharger, split cooling system and direct fuel injection, which provide a surprising level of performance in the three-cylinder engine block.

The 1.0L Ford EcoBoost engine (Fig. 1) allows the new model to be more powerful than the first-generation Ford Focus with a 1.6L engine from less than 10 years ago and produce $47 \%$ less $\mathrm{CO}_{2}$.

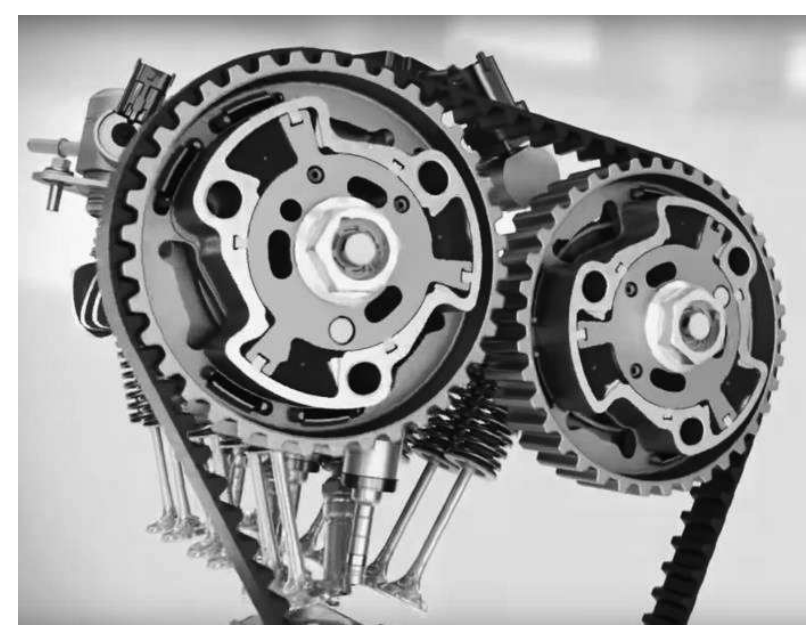

Fig. 1 General view of the Ford Focus 1.0 l EcoBoost engine [1]

The component from the Ford Focus 1.0L EcoBoost engine was analyzed, namely one of a pair of materially identical aluminum gears connected by a drive pulley and a drive (Fig. 2 - marked with arrows). Aluminum gear components are surface treated with a mixture of metal powders using PVD technology [2- 
8]. The goal of the coating is to increase the hardness, abrasion resistance and heat of the base material. With PVD technology, there is no or only a very limited diffusion bonding layer between the coating and the substrate (coated material), a sharp interface remains and the adhesion forces are realized only by the physical principle.

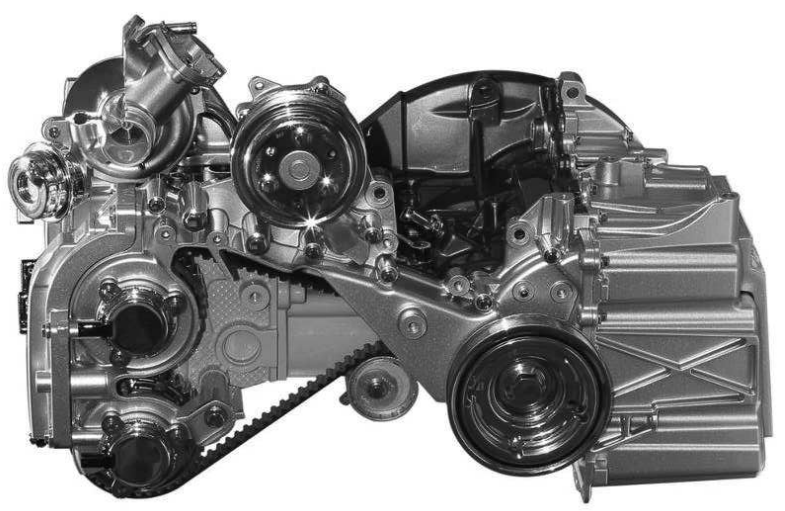

Fig. 2 Ford Focus 1.0 l EcoBoost engine after partial disassembly, indicating the location of the component to be analyzed

\section{Description of the analyzed component and analysis of the basic material}

One gear connected to a drive pulley was used for analysis. Samples were taken from the coated wheel in the whole cross section (Fig. 3, 4) for chemical analysis of the base materiál. Layer thickness measurements were also performed as well as samples taken for EDS analysis of the coating composition on a scanning electron microscope.

The analysis of the basic material of the component was performed using a Q4 spark spectrometer at three different locations. The chemical composition of the base material of the aluminum gear wheel is shown in Tab. 1 as the average of three measurements. The chemical composition proves that it is a component made by thermoforming and corresponds to the alloy
EN AW6061 (ISO AlMg1SiCu) according to the standard ČSN EN 5731-3.

In terms of chemical composition, it is an $\mathrm{AlMgSi}$ alloy with a low copper content as an accompanying (alloying) element [9-14]. The addition of a small amount of $\mathrm{Cu}$ will allow the strength of the base aluminum material to be increased by heat treatment by precipitation hardening.

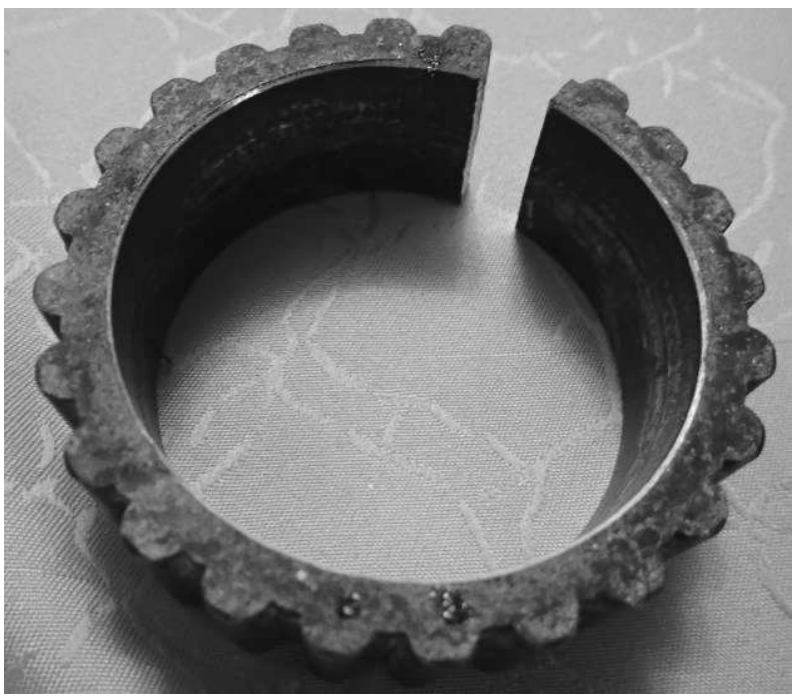

Fig. 3 General cross-sectional view of the part with the sampling point for analysis

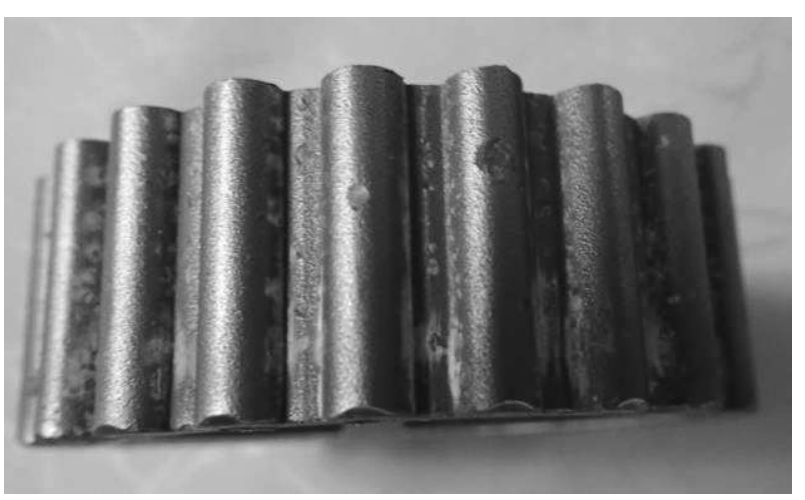

Fig. 4 Part of the part taken for EDS coating analyzes

Tab. 1 Chemical composition of the basic material of the engine drive gear

\begin{tabular}{|c|c|c|c|c|c|c|c|c|c|}
\hline \multicolumn{10}{|c|}{ Chemical composition [wt. \%] } \\
\hline $\mathrm{Si}$ & $\mathrm{Fe}$ & $\mathrm{Cu}$ & $\mathrm{Mn}$ & $\mathrm{Mg}$ & $\mathrm{Cr}$ & $\mathrm{Zn}$ & $\mathrm{Pb}$ & $\mathrm{Ti}$ & $\mathrm{Al}$ \\
\hline 0.69 & 0.28 & 0.31 & - & 0.81 & - & - & - & - & 97.91 \\
\hline
\end{tabular}

\section{Metallographic analysis of the part in section and measurement of the coating thickness}

To examine the microstructure of the part, three metallographic sections were prepared, where one of them was taken to examine the structure of the parent metal and two other to measure the thickness of the coating [15]. Examination of the microstructure, coating compactness and coating thickness measurement was performed using an Olympus LEXT OLS 3100 confocal microscope. The microstructure of the component shows fine intermetallic phases of maximum occurrence of larger inclusions and/or porosity (Fig. 5). In terms of microstructure and gear shape, the part was made by profile extrusion in the shape of a profile. The microstructure in the cross-section in the area of the coating shows that the part has a continuous surface layer formed without a defect and even in the area of the tooth arc (Fig. 6 - right part of the coating) there is no reduction in the coating thickness. 


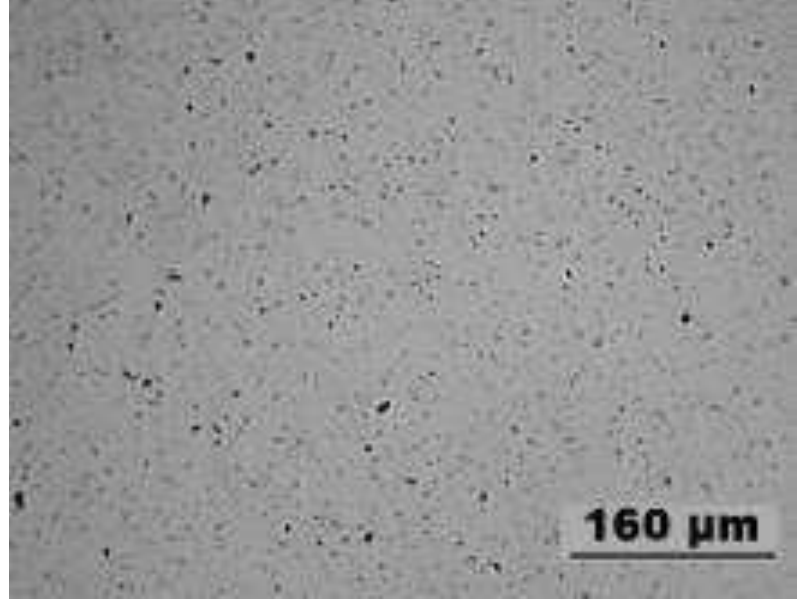

Fig. 5 Microstructure of basic materiál

Measurement of the coating thickness of the component at location A (Fig. 7) demonstrates in cross section that the component exhibits a continuous surface layer formed by powder metallography, which ranges in a narrow range from $70.1 \mu \mathrm{m}$ to $95.6 \mu \mathrm{m}$ (Tab. 2).

The measurement was performed at 10 different locations and the measurement results are shown in the Table 2.

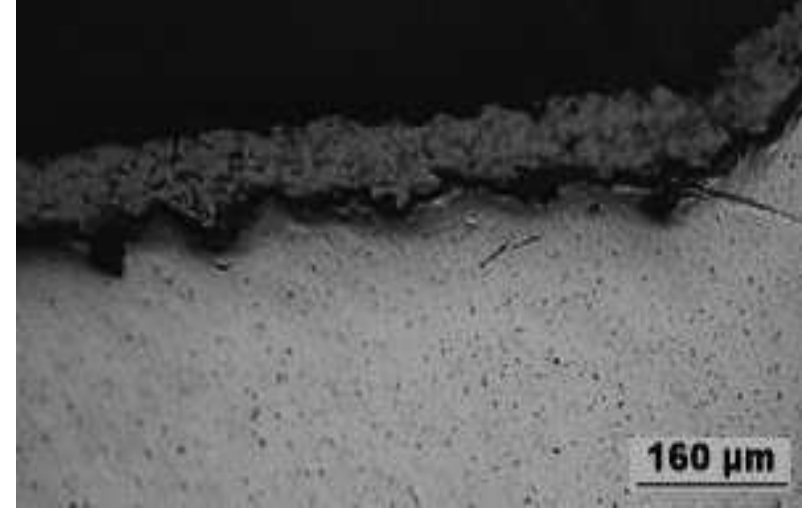

Fig. 6 Base material with coating

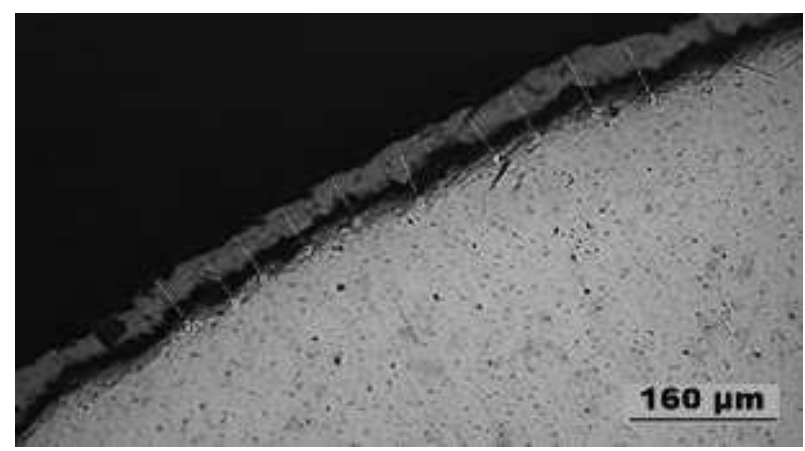

Fig. 7 Measurement of the coating thickness of the component at point $A$ in 10 places

Tab. 2 Results of coating thickness measurement at location $A$

\begin{tabular}{|c|c|c|c|c|c|c|c|c|c|c|c|}
\hline Measurement number & $\mathbf{1}$ & $\mathbf{2}$ & $\mathbf{3}$ & $\mathbf{4}$ & $\mathbf{5}$ & $\mathbf{6}$ & $\mathbf{7}$ & $\mathbf{8}$ & $\mathbf{9}$ & $\mathbf{1 0}$ & $\begin{array}{c}\text { Average } \\
\text { value }\end{array}$ \\
\hline $\begin{array}{c}\text { Measured layer } \\
\text { thickness }[\boldsymbol{\mu m}]\end{array}$ & 95.6 & 91.1 & 78.8 & 83.6 & 93.8 & 70.1 & 70.8 & 71.1 & 80.8 & 74.3 & 81.0 \\
\hline
\end{tabular}

Measurement of the coating thickness of the component at location B (Fig. 8) shows in cross section that the component has a continuous surface layer formed by powder metallography, which ranges in a narrow range from $96.5 \mu \mathrm{m}$ to $143.9 \mu \mathrm{m}$ (Tab. 3).

The measurement was performed in 10 different places and the measurement results are in the Tab. 3 .

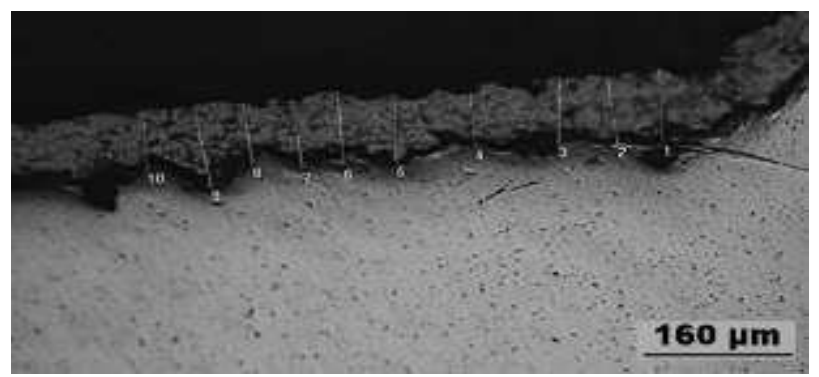

Fig. 8 Measurement of the coating thickness of the component at point B in 10 places

Tab. 3 Results of coating thickness measurement at location $B$

\begin{tabular}{|c|c|c|c|c|c|c|c|c|c|c|c|}
\hline $\begin{array}{l}\text { Measurement } \\
\text { number }\end{array}$ & 1 & 2 & 3 & 4 & 5 & 6 & 7 & 8 & 9 & 10 & $\begin{array}{c}\text { Average } \\
\text { value }\end{array}$ \\
\hline $\begin{array}{l}\text { Measured layer } \\
\text { thickness }[\mu \mathrm{m}]\end{array}$ & 130.1 & 118.6 & 116.3 & 96.5 & 118.8 & 129.1 & 122.5 & 108.5 & 143.9 & 101.4 & 118.6 \\
\hline
\end{tabular}

\section{Analysis of the coating using scanning electron microscopy and EDS analysis}

A Tescan VEGA 3 scanning electron microscope equipped with a Bruker EDX analyzer was used for chemical analysis of the coating and surface morphology. As part of the microscopic analysis by electron microscopy, the surface coating was analyzed from selected locations. In terms of morphology and different local coloration of the coating, two different sites can be identified, which were subsequently analyzed by EDX analysis. In terms of coating morphology, two distinct sites can be identified, namely irregular light areas that occupy about $60 \%$ of the coating surface 
and dark irregular areas that occupy about $40 \%$ of the component coating surface (Figs. 9, 10). Both different areas were then subjected to area EDX analyzes.

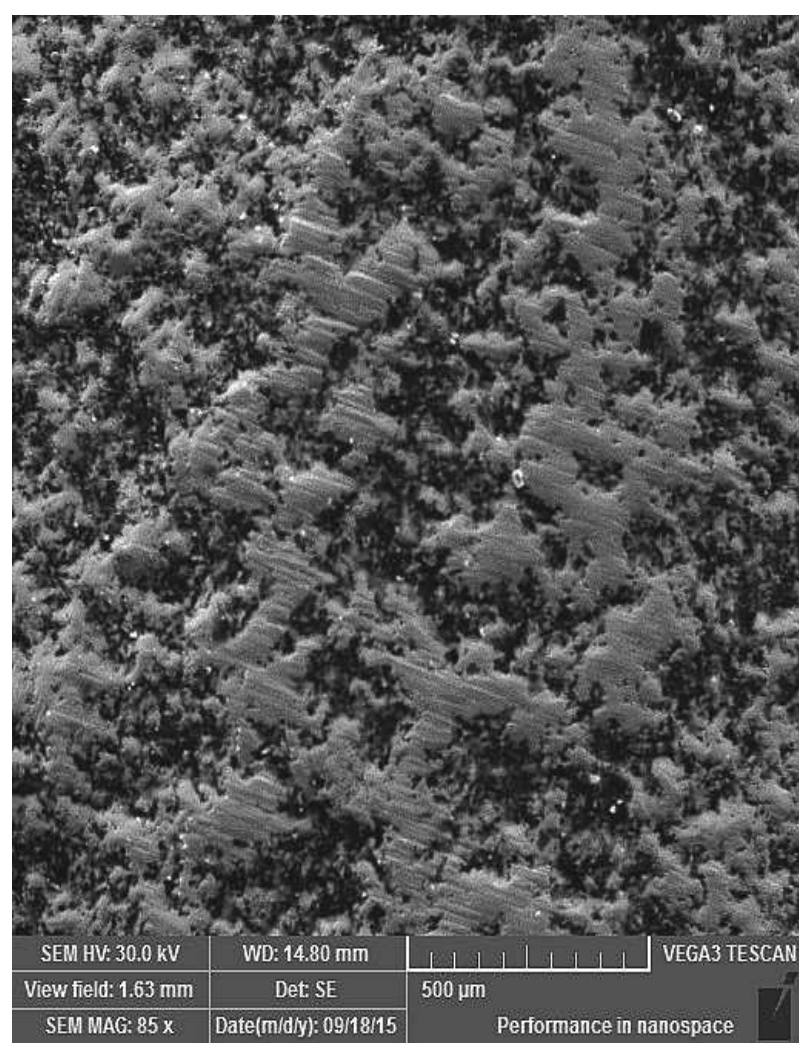

Fig. 9 Morphology and structure of the coating of the surface component

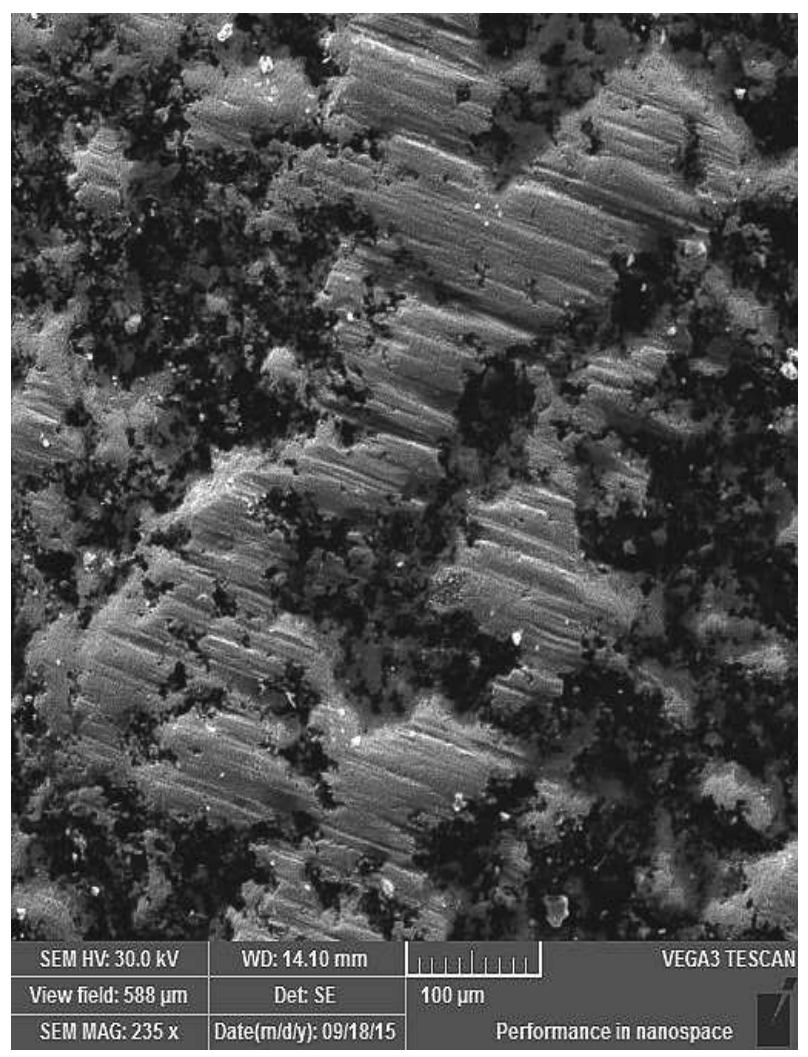

Fig. 10 Detail of the surface of a component coating with light and dark areas
Area EDX analysis of the dark part of the surface proves that it is formed by powder-coated tungsten carbides and the bonding material is cobalt. From the point of view of quantitative analysis, it can be stated that there is more tungsten carbide in the dark area, where the analysis shows $35.33 \%$ of tungsten and $40.23 \%$ of carbon. The binding cobalt is $4.28 \%$ and there is also a high oxygen content is $16.79 \%$, which is related to the coating technology and the oxide surface of the aluminum profile.

\section{EDS coating analysis - black area}

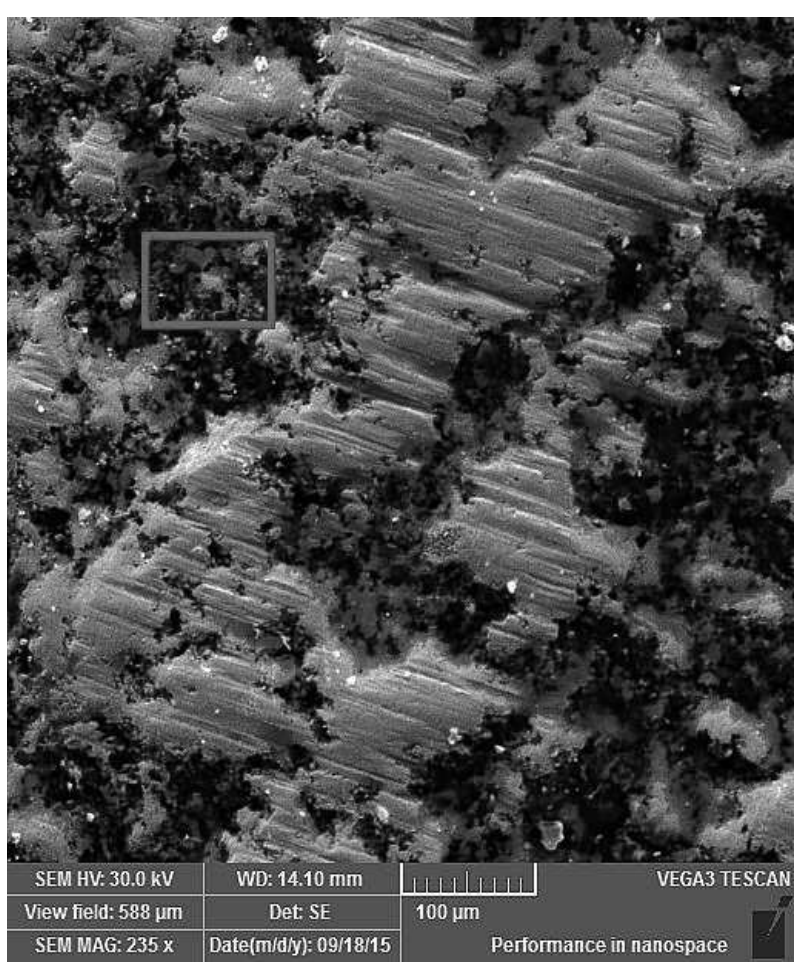

Fig. 11 Place of area EDX analysis of the dark part on the surface.

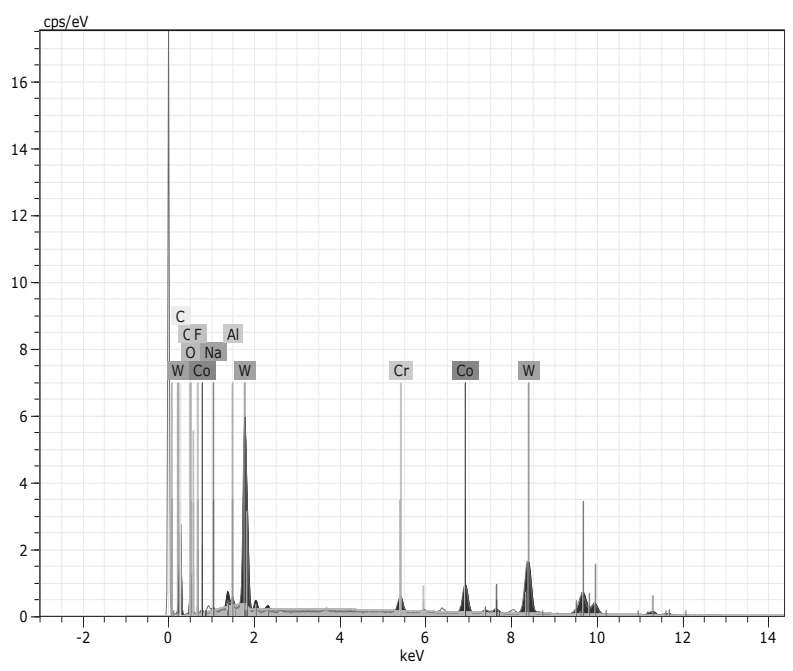

Fig. 12 Surface EDX analysis from visible area in Fig.11

Tab 4 shows the elements that are identified from EDS analysis of the region visible on Fig. 12. 
Tab. 4 Results of EDX analysis from the area visible in Fig. 12

\begin{tabular}{|c|c|c|c|c|c|}
\hline $\begin{array}{l}\vec{\Xi} \\
\vec{\Xi} \\
\frac{\vec{U}}{\mid I I}\end{array}$ & $\cdot \frac{\mathscr{d}}{\infty}$ & 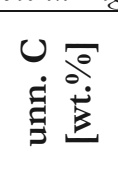 & 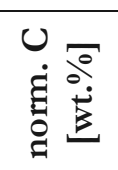 & 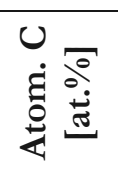 & 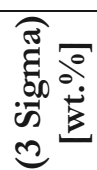 \\
\hline Al & K-series & 0.46 & 0.42 & 0.32 & 0.17 \\
\hline $\mathbf{O}$ & K-series & 18.51 & 16.79 & 21.96 & 9.48 \\
\hline W & K-series & 38.94 & 35.33 & 4.02 & 3.03 \\
\hline $\mathbf{F}$ & K-series & 1.18 & 1.07 & 1.18 & 1.26 \\
\hline Co & K-series & 4.72 & 4.28 & 1.52 & 0.47 \\
\hline $\mathrm{Cr}$ & K-series & 1.68 & 1.53 & 0.61 & 0.24 \\
\hline $\mathbf{N a}$ & K-series & 0.38 & 0.35 & 0.32 & 0.20 \\
\hline C & K-series & 44.34 & $40-23$ & $70-07$ & 19.70 \\
\hline Total: & & 110.21 & 100.00 & 100.00 & \\
\hline
\end{tabular}

\section{EDS coating analysis - bright area}

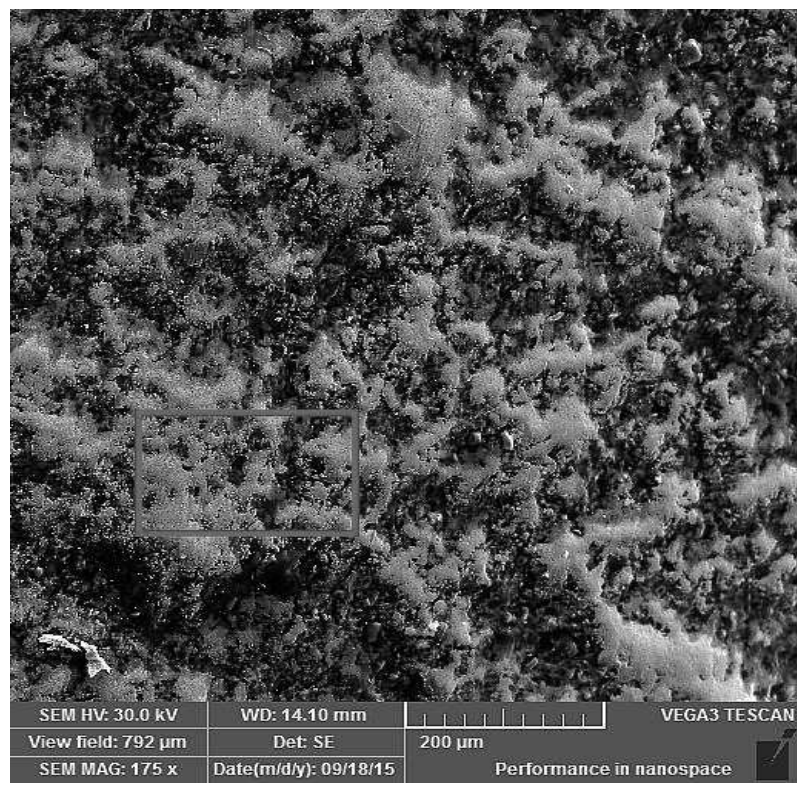

Fig.13 Place of area EDX analysis of the dark part on the surface.

Area EDX analysis of the light part of the surface proves that it consists of powder-coated tungsten carbides and the bonding material is cobalt. From the point of view of quantitative analysis, it can be stated that there is more tungsten carbide in the dark area, where the analysis shows 66.63 wt. \% of tungsten and 16.54 wt. $\%$ of carbon. The binding cobalt is $6.39 \%$ by volume and there is also a high oxygen content of $7.89 \%$, which is related to the coating technology and the oxide surface of the aluminum profile. The light area contains almost 100\% more tungsten and less carbon, indicating a higher tungsten carbide content compared to the dark area. The binding area of cobalt also contains more bright area and contains about $100 \%$ less oxygen.

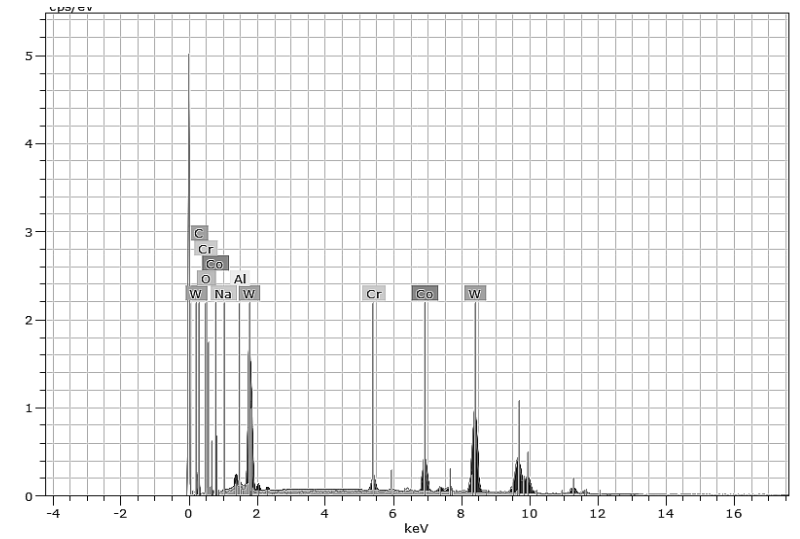

Fig. 14 Surface EDX analysis from visible area in Fig.13

Tab 4 shows the elements that are identified from EDS analysis of the region visible on Fig. 14.

Tab. 5 Results of EDX analysis from the area visible in Fig. 14

\begin{tabular}{|c|c|c|c|c|c|}
\hline 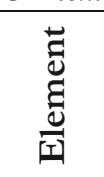 & . & 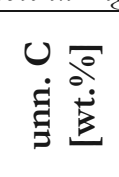 & ن & 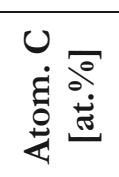 & 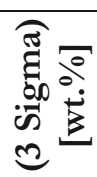 \\
\hline Al & K-series & 0.39 & 0.34 & 0.53 & 0.20 \\
\hline $\mathbf{O}$ & K-series & 8.99 & 7.89 & 20.53 & 7.87 \\
\hline W & K-series & 75.97 & 66.63 & 15.09 & 6.02 \\
\hline C & K-series & 18.86 & 16.54 & 57.33 & 14.62 \\
\hline Co & K-series & 7.29 & 6.39 & 4.51 & 0.78 \\
\hline $\mathrm{Cr}$ & K-series & 2.24 & 1.97 & 1.57 & 0.36 \\
\hline $\mathbf{N a}$ & K-series & 0.28 & 0.24 & 0.44 & 0.23 \\
\hline Total: & & 114.02 & 100.00 & 100.00 & \\
\hline
\end{tabular}




\section{Conclusion}

The chemical composition of the basic material of the geared aluminum drive wheel of the FORD engine proves that it is a component made by thermoforming and corresponds to the alloy EN AW 6061 (AlMg1SiCu) according to the standard ČSN EN 573 1-3. The microstructure of the component of the base material shows fine intermetallic phases up to a size of max. $10-15 \mathrm{~mm}$. All the intermetallic phases are evenly distributed in the whole cross-section of the base material of the component, without the occurrence of larger inclusions and/or porosity.

In terms of microstructure and gear shape, the part was made by profile extrusion in the shape of a profile. The cross-sectional microstructure in the region of the coating shows that the component has a continuous uniform surface layer of the coating formed without a defect. Even in the region of the toothed arc and does not have a diffuse connection with the base material.

The measurement of the coating thickness of the component was performed at two different locations, and the results demonstrate that the component exhibits a continuous surface layer formed by powder metallography that ranges in the narrow range from 70.1 $\mu \mathrm{m}$ to $143.9 \mu \mathrm{m}$. The surface EDX of the surface proves that it consists of deposited tungsten carbides produced by powder metallography and the bonding material is cobalt. Area EDX analysis of the surface coating identified morphologically two distinct areas of dark and light, where tungsten carbides and cobalt are based, and only the tungsten carbide and cobalt carbide contents change. The oxygen and carbon content also changes in the dark and light areas.

\section{Acknowledgement}

Supported by the OP VVV Project Development of new nano and micro coatings on the surface of selected metallic materials - NANOTECH ITI II., Reg. No CZ.02.1.01/0.0/0.0/18_069/0010045

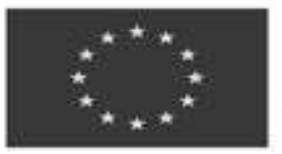

EUROPEAN UNION

European Structural and Investment Funds

Operational Programme Research.

Development and Education

\section{References}

[1] Green Car Congress. BioAge Group, LLC. 2004-2021 [online] https://www.greencarcongress.com/2013/08/ford-20130812.html

[2] MICHNA Š., LUKÁČ I., OČENÁŠEK V., KOŘENÝ R. LOUDA P., DRÁPALA J., SCHNEIDER H., MIŠKUFOVÁ A. (2007). Aluminium Materials and Technologies from $A$ to $Z$., Slovak Republic, Adin s.r.o, Prešov 2007, ISBN 80-89041-4.

[3] MONDOLFO, L. F. (1979). Aluminium Alloys, Structure and Properties. Butterworths, London, 1979. $986 \mathrm{p}$.

[4] MATTOX, D. (2010). Handbook of physical vapor deposition (PVD) processing: principles, technology, and applications. 2nd ed. Amsterdam: Elsevier, XLVI, 746 p. ISBN 978-0-81-552037-5

[5] K. D. BOUZAKIS, N. MICHAILIDIS, G. SKORDARIS, E. BOUZAKIS, D. BIERMANN, R. M'SAOUBI. (2012). Cutting with coated tools: coating technologies, characterization methods and performance optimization. CIRP Ann. - Manuf. Technol., Vol. 61, No. 2, pp. 703-72. ISSN 0007-8506.

[6] ALI, M., HAMZAH, E., QAZI, I.A.,. TOFF, M.R.M. (2010). Effect of cathodic arc PVD parameters on roughness of TiN coating on steel substrate. Curr. Appl. Phys., Vol. 10, No. 2, pp. 471-474.

[7] JAROS, A., FIALA Z. (2016). Investigation of the Influence of PVD Coatings Deposited on HSS Milling Cutter. Manufacturing Technology, Vol. 16, N. 3, pp. 506-512. ISSN 1213-2489.

[8] NOVOTNÝ, J., LYSOŇKOVÁ, I., CAIS, J., MICHNA, S. (2019). Comparative aspects of nanoparticles in relation to extending shelf life of molds. In Advances in Science and Technology Research Journal, Vol. 13, Issue 1, pp. 110-115. ISSN 2299-8624.

[9] MICHNA, Š., HREN, I., MICHNOVA, L. (2020). Alloying of aluminum alloys with pure chromium particles. Metallurgist, Vol. 64, pp. 82 89. ISSN 1573-8892.

[10] HREN, I, MICHNA, Š, SVOBODOVA, J, MICHNOVA, L, BENES, L. (2020). The analysis of the defects occurrence on the functional surfaces of individual mould segments for the tyre production from AlSi7Mg0.3Sr. Journal of Mechanical Engineering Science, Part C, Vol. 234, No. 17, pp. 3474-3483. ISSN: 0954-4062.

[11] MICHNA, Š., HREN I., CAIS J., MICHNOVÁ L. (2020). The Research of the Different Properties and Production Parameters having Influence on Deep-Drawing Sheets 
made of AlMg3 Alloy, Manufacturing Technology, Vol. 20, No. 3, pp. 318-327. ISSN 1213-2489.

[12] NOVOTNY, J., MICHNA, Š., HREN, I., CAIS, J., LYSONKOVA, I., SVORCIK, V. (2021). PTFE Based Multilayer Micro-Coatings for Aluminum AlMg3 Forms Used in Tire Production. Coatings, Vol. 2, pp. 1-11. EISSN 20796412.

[13] ŠERÁK, J., VOJTĚCH, D., ŠIMON, C. (2020). The influence of thermal history on the microstructure and mechanical properties of AlSi8Cu2Fe alloy, Manufacturing Technology, Vol. 20, No. 4, pp. 521-526. ISSN 1213-2489.
[14] LIPIŃSKI, T. (2019). Effect of Sr, Ti and B Additions as Powder and a Preliminary Alloy with $\mathrm{Al}$ on Microstructure and Tensile Strength AlSi9Mg Alloy, Manufacturing Technology, Vol. 19, No. 5, pp. 807-812.

[15] KRAUS, P., HREN, I., NÁPRSTKOVÁ, N., MICHNA, Š., MICHNOVÁ, L., ABOLTINS, A. (2020). Laser Micro-Coating of Stainless Steel on an Al-Si Cast Alloy. Engeeniring for Rural Development, N. 20, pp. 503-508, ISSN 1691 5976. 